\title{
Isolation, identification and insecticidal effects of entomopathogenic bacteria from the willow flea beetle, Crepidodera aurata (Coleoptera; Chrysomelidae)
}

\author{
Izolacja, identyfikacja i owadobójcze działanie entomopatogenicznych \\ bakterii wyizolowanych z Crepidodera aurata (Coleoptera; Chrysomelidae)
}

\author{
Mustafa Yaman ${ }^{1,2 *}$, Ömer Ertürk ${ }^{3}$
}

\begin{abstract}
Summary
In the presented study, a bacterial flora of an important poplar pest, the willow flea beetle Crepidodera aurata (Coleoptera) was studied for the first time to propose ecologically alternative control agents. The five species of entomopathogenic bacteria, four nonspore forming and one spore forming: Staphylococcus aureus, Staphylococcus sciuri, Bacillus circulans, Bacillus thuringiensis and Kocuria kristinae were identified. Bioassay experiments showed that all isolated bacteria have insecticidal effect on the adults of C. aurata. Based on the results of mortality in the adults of $C$. aurata resulting from an application of different bacterium species it was concluded that $B$. thuringiensis might be the most potential bacterium control agent $(69.2 \%$ mortality) then $B$. circulans (53.8\%), S. aureus (54.5\%), S. sciuri (66.6\%), and K. kristinae (60\%). This is the first study on the bacterial pathogens of $C$. aurata.
\end{abstract}

Key words: Crepidodera aurata; biological control; entomopathogenic bacteria; poplar

\section{Streszczenie}

Celem przeprowadzonych badań było oznaczenie flory bakteryjnej występującej na szkodniku topoli Crepidodera aurata (Coleoptera), z uwzględnieniem opracowania alternatywnych, ekologicznych środków zwalczania. Zidentifikowano pięć gatunków entomopatogenicznych bakterii, z których Staphylococcus aureus, Staphylococcus sciuri, Bacillus circulans, Bacillus thuringiensis należą do grupy nieformującej zarodników i jeden gatunek Kocuria kristinae - zakwalifikowany do grupy tworzącej zarodniki. Przeprowadzone testy biologiczne wykazały owadobójcze właściwości wszystkich wyizolowanych gatunków bakterii, przy czym śmiertelność dorosłych osobników C. aurata wynosiła przy zastosowaniu B. thuringiensis $69,2 \%$, B. circulans 53,8\%, S. aureus 54,5\%, S. sciuri $66,6 \%$ i $K$. kristinae $60 \%$. Gatunek B. thuringiensis może być potencjalnym gatunkiem wykorzystywanym do zwalczania $C$. aurata. Są to pierwsze badania dotyczące bakteryjnych patogenów szkodnika topoli $C$. aurata.

Słowa kluczowe: Crepidodera aurata; zwalczanie biologiczne; entomopatogeniczne gatunki bakterii; topola

\footnotetext{
${ }^{1}$ Department of Biology, Faculty of Science, Karadeniz Technical University, 61080, Trabzon, Turkey

${ }^{2}$ Faculty of Education, Ordu University, Ordu, Turkey

${ }^{3}$ Department of Biology, Faculty of Art and Science, Ordu University, Ordu, Turkey

*corresponding author: yaman@ktu.edu.tr
} 


\section{Wstęp / Introduction}

The willow flea beetle Crepidodera aurata (Coleoptera) is a forestry-important species of flea beetles from the family Chrysomelidae, especially known as pest of poplars and willow sand observed in Turkey, Czech Republic, Japan and Poland in recent decades (Aslan 1997; Mikhailov and Hayashi 2002; Czerniakowski 2005; Kaygın and Yıldız 2007; Waleryś and Sądej 2008; Czerniakowski 2010; Urban 2011; Czerniakowski and Zadorożny 2012). It causes damages on plants by feeding and leaving round holes on poplar and willows leaves.

Chemical insecticides are the most widely known matters used to control plant pest insects despite their negative effects on the environment. Control decisions for poplar pests should be taken into account ecological and social factors (de Tillesse et al. 2007). Therefore the investigation of environmentally safely control methods for pest control is the main objective for numerous scientists (Andreev et al. 2008; Kutinkova et al. 2008). Microorganisms such as viruses, bacteria, protists, fungi and nematodes which are known as entomopathogen affecting and killing pest insects, and most of them are essentially nonpathogenic to wild life, human and the other non-target organisms such as benifical insects including predators, parasitoids and pollinators. Entomopathogenic bacteria are of great interest to control insect pests. After a great experience with Bacillus thuringiensis, novel entomopathogenic bacteria have been discovered and developed in the last decades (Sidor 1979; Yaman et al. 2000; Yaman 2003; Ruiu et al. 2013). With this aim, several entomopathogenic studies on the different poplar pests have been carried out efficiently (Cavalcaselle 1975; Sidor and Jodal 1986; Vriesen and Keller 1994; Ziemnicka 2007). Unfortunately, there is no any record on the entomopathogenic bacteria, which can be used against C. aurata as a control agent. Furthermore, there is no any study on the entomopathogenic organisms of this pest.

In the presented study we aimed at: (1) determine the bacterial community; (2) isolate and identify the entomopathogenic bacteria; and (3) test the insecticidal potential of the identified bacteria of $C$. aurata to decrease the damages caused by this pest on poplar, willow and other forest trees and propose ecologically alternative control agents.

\section{Materiały i metody / Materials and methods}

\section{Próbki owadów oraz izolacje bakterii / Insect samples and bacterial isolation}

C. aurata adults were used for bacterial isolation and bioassays. The adult beetles were collected from two different localities (Table 1). The beetles were examined macroscopically to determine any disease symptom. Dead and living adults exhibiting characteristic disease symptoms such as no feeding and slow moving were selected for bacterial isolation. The adults were individually placed into $70 \%$ ethanol and gently shaken for $3 \mathrm{~min}$ and then washed tree times with distilled water for surface sterilization (Lipa and Wiland 1972; Yaman et al. 1999).
After surface sterilization, depending on insect size, insects were crushed in a sterilized eppendorf tube including sterile distil water. A drop of solution of the crushed insects was taken, diluted 100 times with sterile water and spread on nutrient agar plates. The plates were incubated at $36^{\circ} \mathrm{C}$ for $24-48 \mathrm{~h}$ and then bacterial colonies were selected. Different colony types of bacteria were identified and purified on nutrient agar plate by subculturing (Kuzina et al. 2001). Bacterial strains were maintained for long-term storage in nutrient broth with $15 \%$ glycerol at $-86^{\circ} \mathrm{C}$ for further tests. The isolates were stored at Department of Biology, Faculty of Science, Karadeniz Technical University.

For identification of bacteria, all bacterial isolates were initially stained by Gram stain for Gram-positive or Gramnegative identification and tested for some biochemical reactions (Bucher 1981; Thiery and Frachon 1997; Yaman et al. 1999, 2000, 2002). Then, VITEK bacterial identification systems (bioMerieux, Prod. No; 21341 and 21342) were used for the identification of the isolated bacteria. Additionally Bacillus species were stained for the presence of crystal protein.

\section{Testy biologiczne $\mathrm{z}$ wyizolowanymi gatunkami bakterii Bioassay with the isolated bacteria}

The bacterial isolates were tested against $C$. aurata adults. $C$. aurata adults cause damage by feeding on the leaves of poplar. Therefore the adults were fed with poplar leaves sprayed with the each suspended bacterial cells (Yaman et al. 1999, 2002; Ziemnicka 2007). The control group was fed with poplar leaves sprayed with sterilized water.

Several bioassays tests were carried out using the C. aurata adults. Totally twenty adults were tested for each bioassay during 21 days. For the control, a set of the insects was fed with sterilized distil water. All tested groups were kept at $24-28^{\circ} \mathrm{C}$ and $35-45 \% \mathrm{RH}$ and 18:6 photoperiod in laboratory conditions (Ziemnicka 2007). Observations were carried out daily and dead adults were removed immediately.

\section{Wyniki i dyskusja / Results and discussion}

Microbial pest management programs require a good knowledge of entomopathogenic organisms limiting the number of plant pest insects. Although C. aurata is known as an important poplar and willow pest, there is no any record on the pathogens of this pest. In the presented study we isolated five different entomopathogenic bacteria from the adults of $C$. aurata collected in two different localities for the first time (Table 1). The isolated bacteria were purified, cultured and identified. We also tested their insecticidal potential against $C$. aurata. The five species of bacteria, four non-spore forming and one spore forming; Staphylococcus aureus, Staphylococcus sciuri, Bacillus circulans, Bacillus thuringiensis and Kocuria kristinae were identified. S. aureus, S. sciuri and B. circulans were identified from the Samsun samples and B. thuringiensis and $K$. kristinae were from Akyazi samples. In the literature there is no record on the entomopathogenic 
Tabela 1. Gatunki bakterii wyizolowane z Crepidodera aurata (Coleoptera; Chrysomelidae)

Table 1. Isolated bacteria from Crepidodera aurata (Coleoptera; Chrysomelidae)

\begin{tabular}{c|c|c}
\hline $\begin{array}{c}\text { Numer izolatu } \\
\text { Izolate No }\end{array}$ & $\begin{array}{c}\text { Wyizolowany gatunek bakterii } \\
\text { Isolated bacterium }\end{array}$ & $\begin{array}{c}\text { Roślina żywicielska/Lokalizacja } \\
\text { Host/Locality }\end{array}$ \\
\hline 31 & Staphylococcus aureus & Crepidodera aurata/Samsun \\
\hline 32 & Staphylococcus sciuri & Crepidodera aurata/Samsun \\
\hline 34 & Bacillus circulans & Crepidodera aurata/Samsun \\
\hline 37 & Bacillus thuringiensis & Crepidodera aurata/Akyazı \\
\hline 38 & Kocuria kristinae & Crepidodera aurata/Akyazı \\
\hline
\end{tabular}

organisms from C. aurata. These bacterial species are the first report from $C$. aurata.

The members of the genera Bacillus and Staphylococcus were isolated most commonly from the pest insect. These genera include entomopathogenic bacterial species isolated from insects (Yaman et al. 1999, 2000, 2002, 2005, 2010; Kuzina et al. 2001; Darriet and Hougard 2002; Yaman 2003; Aslan et al. 2005; Ertürk et al. 2008; Manimegalai and Shanmugam 2013). The members of Staphylococcus, $S$. aureus and $S$. sciuri were isolated from the pest's population in Samsun. Different Staphylococcus species have been isolated from insects (Yaman et al. 2002; Nagaraju et al. 2012; Kat1 and Kat1 2013; Manimegalai and Shanmugam 2013). Recently Nagaraju et al. (2012) isolated $S$. aureus from termites and Manimegalai and Shanmugam (2013) from mulberry silkworm, Bombyxmori (Lepidoptera: Bombycidae). Kat1 and Kat1 (2013) isolated S. sciuri from Xylosandrus germanus (Blandford) (Coleoptera: Curculionidae). Podgwaite et al. (2013) found that $S$. sciuri is the most common isolate associated with adults of the Asian long horned beetle (Coleoptera: Cerambycidae). Both Staphylococcus species were isolated from $C$. aurata for the first time.

$B$. circulans and B. thuringiensis were also isolated from the pest populations in both localities. Members of the genus Bacillus were found most commonly in soil and insect populations. It is known that most species of Bacillus are insect pathogens and have different insecticidal effects (Dulmage 1981; Deacon 1983; Brooks et al. 1988; Yaman and Demirbağ 2000; Darriet and Hougard 2002; Yaman 2003; Ertürk et al. 2008). Thiery and Frachon (1997) mentioned that twenty two Bacillus species are most frequently found in nature and well-recognized worldwide. Darriet and Hougard (2002) isolated a new strain of $B$. circulans from a larva of Culex quinquefasciatus. Brooks et al. (1988) isolated this bacterium from Epargyreusclarus (Cramer) (Lepidoptera: Hesperidae). Subramanyam et al. (1992) isolated and characterized $B$. circulans in a filariasis endemic area. Another bacterium isolated from $C$. auratain in this study is Kocuria kristinae. Cockburn et al. (2013) isolated and identified this bacterium from the common bed bug, Cimex lectularius.
During the study we also tested the insecticidal potential of the isolated bacteria against $C$. aurata. Bioassay experiments showed that all isolated bacteria have insecticidal effect on the adults of $C$. aurata. B. thuringiensis was the most potential bacterium causing $69.2 \%$ mortality in the adults of C. aurata. B. circulans caused $53.8 \%$, S. aureus $54.5 \%$, S. sciuri $66.6 \%$ and K. kristinae $60 \%$ mortality in the adults. Darriet and Hougard (2002) found that B. circulans isolated from a larva of Culex quinquefasciatus has showed larvicidal activity on 3 mosquitoes of medical importance. Furthermore they showed that this isolate 107 times was more toxic to Aedesa egypti when compared to Bacillus sphaericus strain 2362 and at least as pathogenic as $B$. thuringiensis var. israelensis in Aedesa egypti. Brooks et al. (1988) found that B. circulans was most effective isolate against Heliothis zea larvae, following an isolate of $B$. thuringiensis. Shakoori et al. (1999) isolated B. thuringiensis and B. circulans from soil and found 82 and 9\% mortalities against housefly, Musca domestica, respectively. Sturz and Kimpinski (2004) found that this bacterium possessed activity against root-lesion nematodes around the root zone of potatoes in soils.

C. aurata is one of the most common pests of poplars and willows, and there is no another study on the entomopathogenic organisms of this pest for biological control. Furthermore studies on the biological control, especially microbial control strategies against poplar pests have been omitted. There are a few studies on using living microorganisms for the control of harmful insects on poplars (Cavalcaselle 1975; Sidor and Jodal 1986; Vriesen and Keller 1994; Ziemnicka 2007). Therefore the results of the entomopathogenic studies on poplar pests would be of great importance to find some safe and effective pest control strategies. At this point, the results of this study are of great interest to propose some effective entomopathogenic bacteria against one of the important poplar and willow pest, C. aurata.

\section{Podziękowanie / Acknowledgements}

The study was financially supported as a research project by the Scientific and Technological Council of Turkey (1120807). 


\section{Literatura / References}

Andreev R., Kutinkova H., Baltas K. 2008. Non-chemical control of some important pests of sweet cherry. Journal of Plant Protection Research 48 (4): 503-508.

Aslan İ. 1997. Erzurum ilinde söğüt (Salix spp.) ve kavak (Populus spp.) zararlısı yaprak böcekleri (Coleoptera, Chrysomelidae). İstanbul Üniversitesi Orman Fakültesi Dergisi 47: 81-88.

Aslan İ.S., Çoruh S., Özbek H., Yaman M., Şahin F. 2005. Brevibacillus agri, a pathogenic bacterium of Malacosoma neustria (Lepidoptera: Lasiocampidae). Fresenius Environmental Bulletin 14: 98-100.

Brooks C.B., Green B.M., Frank G.R. 1988. Susceptibility of Heliothis zea to bacilli isolated from Epargyreus clarus. Journal of Invertebrate Pathology 52 (1): 177-179.

Bucher G.E. 1981. Identification of bacteria found in insects. p. 10-30. In: "Microbial Control of Pest and Plant Diseases" (H.D. Burges, ed.). Academic Press, London.

Cavalcaselle B. 1975. Possibility of using products based on Beauveria bassiana against the larvae of some wood-eating insects. Mededelingen van de Faculteit Landbouwwetenschappen Rijksuniversiteit Gent 40 (2, I): 437-422.

Cockburn C., Amoroso M., Carpenter M., Johnson B., McNeive R., Miller A., Nichols A.E., Riotto A., Rzepkowzski A., Croshaw C.M.S., Seifert K., Vaidyanathan R. 2013. Gram-positive bacteria isolated from the common bed bug, Cimex lectularius L. Entomologica Americana 119 (1\& 2): 23-29.

Czerniakowski Z.W. 2005. Szkodliwe owady w matecznikach wierzby energetycznej. [Noxious insects in energy willow coppice nurseries]. Progress in Plant Protection/Postępy w Ochronie Roślin 45 (1): 77-81.

Czerniakowski Z.W. 2010. Bioróżnorodność szkodliwej entomofauny na wierzbach w południowo-wschodniej Polsce. [Biodiversity of noxious entomofauna on willows in south-eastern Poland]. Fragmenta Agronomica 27 (4): 19-24.

Czerniakowski Z.W., Zadorożny Ł. 2012. Występowanie chrząszczy (Coleoptera) na wierzbach szerokolistnych. [Occurrence of beetles (Coleoptera) species on broad leaf willows]. Progress in Plant Protection/Postępy w Ochronie Roślin 52 (4): 817-819.

Darriet F., Hougard J.M. 2002. An isolate of Bacillus circulans toxic to mosquito larva. Journal of the American Mosquito Control Association 18: 65-67.

Deacon J.W. 1983. Microbial Control of Plant Pests and Diseases. Published by Van Nostrand Reinhold (UK) Co. Ltd. Molly Millars Lane, Wokingham, Berkshire, 88 pp.

de Tillesse V., Nef L., Charles J., Hopkin A., Augustin S. 2007. Damaging Poplar Insects (Internationally Important Species). International Poplar Commission, FAO, Rome, $105 \mathrm{pp}$.

Dulmage H.T. 1981. Insecticidal activity of isolates of Bacillus thuringiensis and their potential for pest control. p. 193-280. In: "Microbial Control of Pest and Plant Diseases" (H.D. Burges, ed.). Academic Press, London.

Ertürk Ö.,Yaman M., Aslan İ. 2008. Effects of four soil-originated Bacillus spp. on the Colorado potato beetle, Leptinotarsa decemlineata (Say). Entomological Research 38: 135-138.

Kaygın A.T., Yıldız Y. 2007. A threatening species for willows and poplars in Bartın: Crepidodera aurata (Marsh.) (Coleoptera, Chrysomelidae). Türkiye II. Bitki Koruma Kongresi, 27-29 Ağustos 2007, Isparta.

Kat1 A., Kat1 H. 2013. Isolation and identification of bacteria from Xylosandrus germanus (Blandford) (Coleoptera: Curculionidae). African Journal of Microbiology Research 7 (47): 5288-5299.

Kutinkova H., Samietz J., Dzhuvinov V. 2008. Combination of mating disruption and granulosis virus for control of codling moth in Bulgaria. Journal of Plant Protection Research 48 (4): 509-513.

Kuzina L.V., Peloquin J.J., Vacek D.C., Miller T.A. 2001. Isolation and identification of bacteria associated with adult laboratory Mexican fruit flies, Anastrepha ludens (Diptera; Tephritidae). Current Microbiology 42 (4): 290-294.

Lipa J.J., Wiland E. 1972. Bacteria isolated from cutworms and their infectivity to Agrotis sp. Acta Microbiologica Polonica, Seria B, 4: $127-140$.

Manimegalai R.A.S., Shanmugam R. 2013. Morphological and biochemical characterization of bacterial and viral pathogens infecting mulberry silkworm, Bombyx mori L. Trends in Biosciences 6: 407-411.

Mikhailov Y.E., Hayashi M. 2002. Chrysomelidae of Sakhalin II. Entomological Review of Japan 57 (1): 29-46.

Nagaraju K., Meenakshi B.C., Sundararaj R. 2012. Importance of entomopathogenic bacteria to control termites in forest nurseries and plantations. Journal of Pure and Applied Microbiology 6 (4): 1959-1964.

Podgwaite J.D., D'Amico V., Zerillo R.T., Schoenfeldt H. 2013. Bacteria associated with larvae and adults of the Asian longhorned beetle (Coleoptera: Cerambycidae). Journal of Entomological Science 48 (2): 128-138.

Ruiu L., Satta A., Floris I. 2013. Emerging entomopathogenic bacteria for insect pest management. Bulletin of Insectology 66: $181-186$.

Sidor $\mathrm{C}^{\prime} .1979$. The role of insect pathogenic microorganisms in environmental protection. Mikrobiologija 16: 173-186.

Sidor C'., Jodal I. 1986. Nosema melasomae causing a disease of the poplar leaf beetle (Melasoma populi L., Chrysomelidae, Coleoptera). Zaštita Bilja 37 (3): 243-249.

Shakoori A.R., Naheed I., Nazia K. 1999. Evaluation of different species of Bacillus isolated from soil samples as bioinsecticide against housefly, Musca domestica. Pakistan Journal of Zoology 31: 379-383.

Sturz A.V., Kimpinski J. 2004. Endoroot bacteria derived from marigolds (Tagetes spp.) can decrease soil population densities of rootlesion nematodes in the potato root zone. Plant and Soil 262: 241-249.

Subramanyam V., Ramaswamy R.K., Dash A.P. 1992. Characterization of Bacillus spp. isolated from mosquito larvae in a filariasis endemic area. Journal of Communicable Diseases 24: 60-61.

Thiery I., Frachon E. 1997. Identification, isolation, culture and preservation of enthomopathogenic bacteria. p. 55-73. In: "Manual of Techniques in Insect Pathology" (L.A. Lacey, ed.). Academic Press, London, 409 pp.

Urban J. 2011. Occurrence, bionomics and harmfulness of Crepidodera aurea (Geoffr.) (Coleoptera, Alticidae). Acta Universitatis Agriculturae et Silviculturae Mendelianae Brunensis 59 (5): 279-308.

Vriesen S., Keller B. 1994. Screening of different Bacillus thuringiensis isolates against Melasoma populi L. (Coleoptera, Chrysomelidae) and their characterization. 46th International Symposium on Crop Protection. Proceedings, Vols 1-4 Book Series, 59 (2A): 639-642. 
Waleryś G., Sądej W. 2008. Chrząszcze (Coleoptera) zagrażające plantacjom wierzby krzewiastej w okolicach Olsztyna. [The beetles (Coleoptera) threatening shrub willow (Salix spp.) plantations near Olsztyn]. Progress in Plant Protection/Postępy w Ochronie Roślin 48 (3): 993-997.

Yaman M., Demirbă̆ Z., Beldüz A.O. 2000. Isolation and insecticidal effects of some bacteria from Euproctis chrysorrhoea L. (Lepidoptera: Lymantriidae). Acta Microbiologica Polonica 49 (3-4): 217-224.

Yaman M. 2003. Insect bacteria and hazelnut pests biocontrol: The state of the art in Turkey. Rivista di Biologia-Biology Forum 96 (1): $137-144$.

Yaman M., Demirbağ Z., Beldüz A.O. 1999. Investigation on the bacterial flora as a potential biocontrol agent of chestnut weevil, Curculio elephas (Coleoptera: Curculionidae) in Turkey. Biologia 54: 679-683.

Yaman M., Demirbağ Z. 2000. Isolation, identification and determination of insecticidal activity of two insect-originated Bacillus spp. Biologia 55 (3): 283-287.

Yaman M., Nalçacioğlu R., Demirbağ Z. 2002. Studies on bacterial flora in the population of fall webworm, Hyphantria cunea Drury. (Lepidoptera: Arctiidae). Journal of Applied Entomology 126 (9): 470-474.

Yaman M., Aslan İ., Çalmaşur Ö., Şahin F. 2005. Two bacterial pathogens of Helicoverpa armigera (Hübner) (Lepidoptera: Noctuidae). Proceedings of The Entomological Society of Washington 107: 623-626.

Yaman M., Ertürk Ö., Aslan İ. 2010. Isolation of some pathogenic bacteria from the great spruce bark beetle, Dendroctonus micans and its specific predator, Rhizophagus grandis. Folia Microbiologica 55 (1): 35-38.

Ziemnicka J. 2007. Mass production of nucleopolyhedrovirus of the satin moth Leucoma salicis (LesaNPV). Journal of Plant Protection Research 47 (4): 457-467. 